\title{
Comparative Field Performance Study of Flat Plate and Heat Pipe Evacuated Tube Collectors (ETCs) for Domestic Water Heating Systems in a Temperate Climate
}

\author{
Lacour Ayompe \\ Technological University Dublin, lacour.ayompe@tudublin.ie \\ Aidan Duffy \\ Technological University Dublin, aidan.duffy@tudublin.ie \\ Sarah McCormack \\ University of Dublin, Trinity College
}

See next page for additional authors

Follow this and additional works at: https://arrow.tudublin.ie/engschcivart

Part of the Civil Engineering Commons, and the Environmental Engineering Commons

\section{Recommended Citation}

Ayompe, L., Duffy, A., McCormack, S., McKeever, M., Conlon, M.: Comparative Field Performance Study of Flat Plate and Heat Pipe Evacuated Tube Collectors (ETCs) for Domestic Water Heating Systems in a Temperate Climate. Energy, Vol. 36, Issue 5, pp. 3370-3378. May, 2011. doi:10.1016/j.energy.2011.03.034

This Article is brought to you for free and open access by the School of Civil and Structural Engineering at ARROW@TU Dublin. It has been accepted for inclusion in Articles by an authorized administrator of ARROW@TU Dublin. For more information, please contact arrow.admin@tudublin.ie, aisling.coyne@tudublin.ie, gerard.connolly@tudublin.ie.

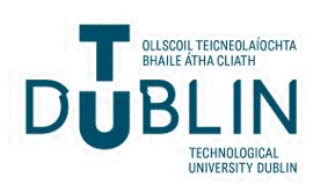




\section{Authors}

Lacour Ayompe, Aidan Duffy, Sarah McCormack, Michael Conlon, and Mick McKeever 


\section{AUTHOR QUERY FORM}

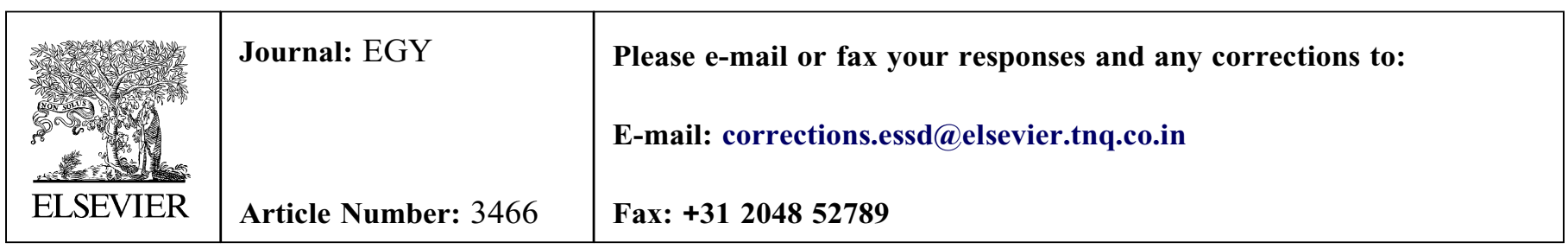

Dear Author,

Please check your proof carefully and mark all corrections at the appropriate place in the proof (e.g., by using on-screen annotation in the PDF file) or compile them in a separate list. To ensure fast publication of your paper please return your corrections within 48 hours.

For correction or revision of any artwork, please consult http://www.elsevier.com/artworkinstructions.

Any queries or remarks that have arisen during the processing of your manuscript are listed below and highlighted by flags in the proof.

\begin{tabular}{|c|l|}
\hline $\begin{array}{c}\text { Location } \\
\text { in article }\end{array}$ & \multicolumn{1}{c|}{$\begin{array}{c}\text { Query / Remark: Click on the Q link to find the query's location in text } \\
\text { Please insert your reply or correction at the corresponding line in the proof }\end{array}$} \\
\hline Q1 & The sentence "The stainless steel hot..." seems to be incomplete. Please check. \\
Q2 & Please provide the year of publication. \\
\hline
\end{tabular}

Thank you for your assistance. 
Energy xxx (2011) 1

Contents lists available at ScienceDirect

Energy

journal homepage: www.elsevier.com/locate/energy

Highlights

- Two domestic scale SWHs with evacuated tube and flat plate collectors (FPCs) were tested under the same conditions. $>$ The annual average collector efficiencies were $46.1 \%$ and $60.7 \%$ for the flat plate and evacuated tube collectors respectively. $>$ System efficiencies were $37.9 \%$ and $50.3 \%$ for the flat plate and ETCs respectively. $>$ Simple payback periods (SPPs) varied between 13 years and 48.5 years depending on the type of auxiliary heating system considered. 


\title{
Comparative field performance study of flat plate and heat pipe evacuated tube collectors (ETCS) for domestic water heating systems in a temperate climate
}

\author{
L.M. Ayompe ${ }^{\mathrm{a}, *}$, A. Duffy ${ }^{\mathrm{a}}$, S.J. McCormack ${ }^{\mathrm{b}}$, M. Conlon $^{\mathrm{c}}$, M. Mc Keever ${ }^{\mathrm{c}}$ \\ ${ }^{a}$ Department of Civil and Structural Engineering, Dublin Institute of Technology, Bolton Street, Dublin 1, Ireland \\ ${ }^{\mathrm{b}}$ Department of Civil, Structural and Environmental Engineering, Trinity College, Dublin 2, Ireland \\ ${ }^{\mathrm{c}}$ Department of Control Systems and Electrical Engineering, Dublin Institute of Technology, Kevin St, Dublin 2, Ireland
}

\section{A R T I C L E I N F O}

Article history:

Received 14 July 2010

Received in revised form

8 March 2011

Accepted 11 March 2011

Available online $\mathrm{xxx}$

\section{Keywords:}

Flat plat collector

Evacuated tube collector

Solar water heater

$\wedge^{\text {Solar fraction }}$

\begin{abstract}
A B S T R A C T
This paper presents a year round energy performance monitoring results of two solar water heaters with $4 \mathrm{~m}^{2}$ flat plate and $3 \mathrm{~m}^{2}$ heat pipe evacuated tube collectors (ETCs)operating under the same weather conditions in Dublin, Ireland. The energy performance of the two systems was compared on daily, monthly and yearly basis. Results obtained showed that for an annual total in-plane solar insolation of $1087 \mathrm{kWh} \mathrm{m}^{-2}$, a total of $1984 \mathrm{kWh}$ and $2056 \mathrm{kWh}$ of heat energy were collected by the $4 \mathrm{~m}^{2} \mathrm{FPC}$ and $\frac{1}{3} \mathrm{~m}^{2}$ ETC systems respectively. Over the year, a unit area of the FPC and ETC each generated $496 \mathrm{kWh} \mathrm{m}^{-2}$ and $681 \mathrm{kWh} \mathrm{m}^{-2}$ of heat respectively. For $3149.7 \mathrm{kWh}$ and $3053.6 \mathrm{kWh}$ of auxiliary energy supplied to the FPC and ETC systems their annual solar fractions (SFs) were $38.6 \%$ and $40.2 \%$ respectively. The annual average collector efficiencies were $46.1 \%$ and $60.7 \%$ while the system efficiencies were $37.9 \%$ and $50.3 \%$ respectively for the FPC and ETC respectively. Economic analysis showed that both solar water heating (SWH) systems are not economically viable with NPVs ranging between $-€ 4,264$ and $-€ 652$ while simple payback periods (SPPs) varied between 13 years and 48.5 years.
\end{abstract}

(c) 2011 Published by Elsevier Ltd.

\section{Introduction}

Solar water heating (SWH) collectors are special kinds of heat exchangers that transform solar energy to the internal energy of a transport medium. They are the major components of a solar system. They absorb incoming solar radiation, convert it to heat and then transfer the heat to a solar fluid usually made up of a mixture of water and glycol that flows through the collector. In forced circulation water heating systems used in temperate climates, the solar fluid is circulated using a pump within a closed circuit. The collected energy is transferred to water in a storage tank via a solar coil installed at the bottom of the tank.

There are three common types of stationary collectors used in SWH systems. These are flat plate collectors (FPCs), evacuated tube collectors (ETCs) and compound parabolic collectors (CPCs). FPCs and ETCs are the most widely deployed collectors for small-scale water heating applications. Both collectors convert beam (direct) and diffuse (in-direct) solar radiation into heat.

Typical domestic installations for families of 4-6 persons in temperate climates consist of $4-6 \mathrm{~m}^{2}{ }_{2} \mathrm{FPCS}$ and $3-4 \mathrm{~m}^{2}{ }_{\Lambda}$ ETCs

\footnotetext{
* Corresponding author. Tel.: +353 14023940; fax: +353 14022997.

E-mail address: lacour.ayompe@dit.ie (L.M. Ayompe).
}

connected to a 200-300 litres hot water tank [1]. Although ETGS are more efficient than their flat plate counterparts, they are however more expensive with $3 \mathrm{~m}^{2}$ heat pipe ETGs costing approximately twice as much as $4 \mathrm{~m}^{2}$ FPGs.

Different authors have investigated the performance of $\mathrm{SWH}$ systems with heat pipe ETGs [2-5] and FPGs [6-9]. Zambolin and Del Col [10] carried out a side by side testing of FPC and ETC in Padova, Italy. They performed steady-state and quasi-dynamic efficiency tests following the EN 12975-2 standard. Allen et al. [11] carried out an integrated appraisal of a solar hot water system in the UK residential sector to asses its overall energy, environmental and economic performance. Kologirou [12] studied the thermal performance, economic and environmental protection offered by thermosiphon $\mathrm{SWH}$ systems.

Roonprasang et al. [13] carried out experimental studies of a new solar water heater system using a solar water pump powered by steam produced from FPGs. Chien et al. [14] experimentally and theoretically investigated a two-phase thermosiphon solar water heater. Huang et al. [15] investigated the thermal performance of thermosiphon flat plate solar water heaters with a mantle heat exchanger in China while Al-Nimr and Akam [16] studied the thermal performance improvements of a conventional tubeless collector. Al-Nimr et al. [17] derived expressions for the optimum length of a flat solar collector that maximizes the life cycle savings 
of the collector and optimal distribution of a finite amount of thermal insulation that minimizes energy loss. Most of these studies have investigated the collectors under operating conditions different from those which are typical of the service life of SWH systems.

This study, therefore, aims to compare the energy and economic performance of FPC and heat pipe ETC systems installed side by side subjected to similar operating conditions and weather conditions to those found in a temperate environment. Energy performance indices computed include: energy output from the collectors, energy delivered to the hot water tanks, collector and system efficiencies, heat loss in the pipes between the collectors and solar coils and $\mathrm{SF}_{\mathrm{S}}$

\subsection{Methodology}

Two complete forced circulation $S W H$ systems with $4 \mathrm{~m}^{2}$ flat plate (FP) and $3 \mathrm{~m}^{2}$ heat pipe evacuated tube (ET) collectors were installed side by side on a flat rooftop and subjected to similar weather and operating conditions in Dublin, Ireland. The two water heating systems each had a 300 hot water tank equipped with an electrical auxiliary immersion heater which was used to top up the tank temperature to $60^{\circ} \mathrm{C}$ in the morning and evening whenever the solar coil fell short of doing so. An automated hot water draw off system was developed which mimicked domestic hot water use; exactly the same hot water demand profile was applied to both SWH systems (shown in Fig. 1). System performance data were collected every minute.

\section{2. $\perp^{\text {System description }}$}

Typical_SWH systems used in temperate climates consist of a hot water storage tank, control unit, pump station and either flat plate or ETGs. The collectors used in this study were installed on a flat roof of the Focas Institute building, Dublin Institute of Technology. They were south facing and inclined at $453^{\circ}$ equal to the local latitude of the location. The hot water cylinders were installed nearby in the building's plant room. The solar circuits consisted of $12 \mathrm{~mm}$ diameter copper pipes insulated with $22 \mathrm{~mm}$ thick Class O Armaflex. All pipe fittings were also insulated to reduce heat losses. The solar circuit pipe length for the ETG supply and return were $14 \mathrm{~m}$ and $15.4 \mathrm{~m}$ respectively while they were $14 \mathrm{~m}$ and $15.6 \mathrm{~m}$ respectively for the FPG system.

The FPC and ETC used in this study are standard commercially available collectors that have been tested to EN 12975/6 standards and certified by the Solar Keymark. The zero-loss collector efficiency, heat loss coefficient, and temperature dependence of the heat loss coefficient values are $0.778,0.91 \mathrm{~W} \mathrm{~m}^{-2} \mathrm{~K}^{-1}$, and $0.01 \mathrm{~W} \mathrm{~m}^{-2} \mathrm{~K}^{-1}$ for the ETC while for the FPC the respective values are $0.776,3.95 \mathrm{~L}_{\mathrm{W}} \mathrm{m}^{-2} \mathrm{~K}^{-1}$, and $0.017 \mathrm{~L}_{\mathrm{W}} \mathrm{m}^{-2} \mathrm{~K}^{-1}$.

\subsection{Evacuated tubes collector}

The evacuated tubes collector was a Thermomax HP200 consisting of a heat pipe solar collector with a row of 30,ETs and an insulated water manifold. It has two separate circuits, one in each individual tube inside the heat pipe and one in the manifold through which the solar fluid circulates. The collector has an absorber surface of $3 \mathrm{~m}^{2}$ and the tubes have a vacuum level of $10^{-5} \mathrm{mbar}$.

\subsection{FPGS}

The FPC system consisted of two K420-EM2L FPGs each with a gross area of $2.18 \mathrm{~m}^{2}$ and aperture area of $2 \mathrm{~m}^{2}$ connected in series giving a total area of $4 \mathrm{~m}^{2}$. Each collector had maximum operating and stagnation temperatures of $120^{\circ} \mathrm{C}$ and $191^{\circ} \mathrm{C}$ respectively, a maximum operating pressure of 10 bar and a fluid content of 1.73 .

\subsection{Hot water tanks}

The stainless steel hot water cylinders (model HM 300L D/coil Q1 U44332). The tank height and diameter were $1680 \mathrm{~mm}$ and $580 \mathrm{~mm}$ respectively with an operating pressure of 3bar. Each cylinder was equipped with two solar immersion heaters of 2.75/ $3.0 \mathrm{~kW}$ capacity located at the bottom and middle of the tank. The cylinders each had two heating coils with surface areas of $1.4 \mathrm{~m}^{2}$ and a rating of $21_{\alpha} \mathrm{kW}$.

\subsection{Hot water demand profile}

The hot water demand profile employed was the EU reference tapping cycle number 3 equivalent to a daily energy output of $11.7 \mathrm{kWh}$ representing 199.8 of water at $60^{\circ} \mathrm{C}$. It is based on hot water use of the average European household described in the European Union mandate for the elaboration and adoption of measurement standards for household appliances EU M324EN [18]. Fig. 1 shows the volume of hot water extracted at different times of the day.

\subsection{Auxiliary heating and hot water demand management system}

A key innovation of the SWH systems field performance test was the introduction of an automated hot water dispensing unit which extracted water from the hot water tanks in such a way as to mimic real life operation where the users interact with the SWH systems. It consists of a programmable logic controller (PLC), contactors, relays, electrical fittings, solenoid valves, thermostats, impulse flow meters, etc. A software code was written to control the auxiliary heating system as well as opening and shutting of the solenoid valves. The operation was synchronised for the two SWH systems to ensure they operated identically.

The PLC turned on the immersion heaters between 5-8 am and 6-9 pm daily just before the two peak hot water draw offs. Analogue thermostats placed at the top of the hot water tanks were set to turn-off the electricities supply to the immersion heaters when the temperature of water at the top of the tank exceeded $60{ }^{\circ} \mathrm{C}$. Hot water was dispensed using solenoid valves that were opened and closed using signals from the PLC. Pulse flow meters ( 1 pulse per litre) installed at the end of the solenoid valves were used to count the number of litres of water extracted from the hot water tanks. The solenoid valves were closed when the required
Fig. 1. Volume of hot water $\left(60^{\circ} \mathrm{C}\right)$ dray off at different times of the day. 


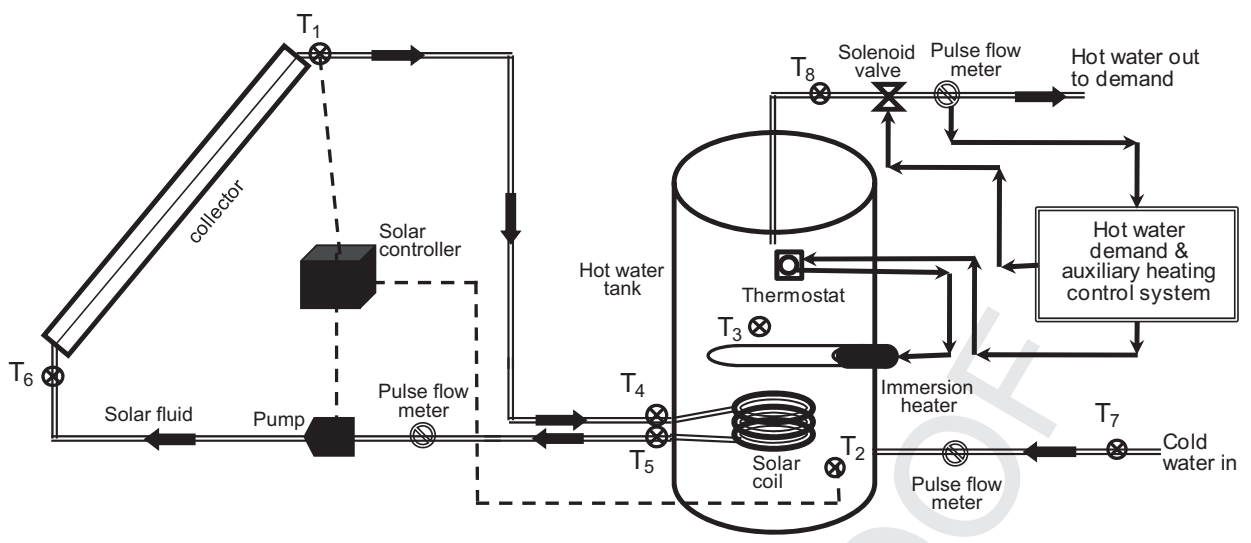

Fig. 2. Schematic diagram of the FPC and ETC systems.

volume of water was dispensed based on the water demand profile (Fig. 1).

Fig. 2 shows a schematic diagram of the experimental setup of the two SWH systems. It shows the location of the SWH system components as well as the position of the thermocouple sensors. Parameters measured include the following: solar fluid temperature at the collector outlet $\left(T_{1}\right)$, water temperature at the bottom of the hot water $\operatorname{tank}\left(T_{2}\right)$, water temperature at the middle of the hot water $\operatorname{tank}\left(T_{3}\right)$, solar fluid temperature at inlet to the solar coil $\left(T_{4}\right)$, solar fluid temperature at the outlet from the solar coil $\left(T_{5}\right)$, solar fluid temperature at inlet to the collector $\left(T_{6}\right)$, cold water inlet temperature $\left(T_{7}\right)$, hot water supply temperature $\left(T_{8}\right)$ and the volume flow rate of the solar fluid.

\subsection{Data measurement and logging}

Each SWH system was equipped with a RESOL DeltaSol M solar controller which had relay inputs to control the operation of the solar pump station. It also had temperature sensor inputs onto which PT1000 platinum resistance temperature sensors were connected to measure water and solar fluid temperatures $\left(T_{1}-T_{8}\right)$ shown in Fig. 2. The volumetric flow rate of the solar fluid was measured using RESOL V40-06 impulse flow meters which react at 10 per pulse. RESOL DL2 data loggers were used to store data every minute from the RESOL DeltaSol M solar controllers via RESOL VBus cables. The DL2 data loggers were equipped with a secure digital (SD) drive and a local area network (LAN) port for direct connection to a personal computer (PC). Data from the loggers was extracted using a Web browser or an SD card and then converted to text format using the RESOL Service Centre Software.

In-plane global solar radiation, ambient temperature and wind speed data were measured using a weather station consisting of an SMA Sunny Sensor Box equipped with an ambient temperature sensor and an anemometer. The solar radiation sensor had an accuracy of $\pm 8 \%$ and a resolution of $1_{\Lambda} \mathrm{W} \mathrm{m}^{-2}$. The PT1000 platinum

Table 1

Technical parameters.

\begin{tabular}{llc}
\hline Description & Units & Value \\
\hline Electric heater efficiency & $(\%)$ & 100 \\
Oil boiler efficiency & $(\%)$ & 65 \\
Condensing natural gas boiler efficiency & $(\%)$ & 90 \\
Heat delivered by ETC & $\mathrm{kWh} \mathrm{y}^{-1}$ & 1699 \\
Heat delivered by FPC & $\mathrm{kWh} \mathrm{y}^{-1}$ & 1639 \\
FPC area for grant calculation & $\mathrm{m}^{2}$ & 4.0 \\
ETC area for grant calculation & $\mathrm{m}^{2}$ & 3.2 \\
\hline
\end{tabular}

temperature sensors had an accuracy of $\pm 0.5^{\circ} \mathrm{C}$ while the ambient temperature sensor was a JUMO PT $100 \mathrm{U}$ type with accuracy of $\pm 0.5^{\circ} \mathrm{C}$. The anaemometer was a Thies small wind transmitter with accuracy of $\pm 5 \%$. Weather data was logged at $5 \mathrm{~min}$ intervals using a Sunny Box WebBox.

\section{Energy analysis}

The energy performance indices evaluated in this study include: energy collected, energy delivered and supply pipe losses, $\mathrm{L}^{\mathrm{SF}}$, collector efficiency and system efficiency.

\subsection{Energy collected}

The useful energy collected by the solar energy collector is given as [19]:

$Q_{\mathrm{c}}=\dot{m} C_{\mathrm{p}}\left(T_{1}-T_{6}\right)$

\subsection{Energy delivered and supply pipe losses}

The useful energy delivered by the solar coil to the hot water tank is given as

$Q_{\mathrm{d}}=\dot{m} C_{\mathrm{p}}\left(T_{4}-T_{5}\right)$

Supply pipe losses were as a result of temperature drop as the solar fluid flowed between the collector outlet and the solar coil inlet to the hot water tank. These losses were calculated as:

$Q_{\mathrm{l}}=\dot{m} C_{\mathrm{p}}\left(T_{1}-T_{4}\right)$

Table 2

Economic parameters.

\begin{tabular}{llc}
\hline Description & Units & Value \\
\hline Electricity cost & $€_{2010} / \mathrm{kWh}$ & 0.160 \\
Gas cost & $€_{2010} / \mathrm{kWh}$ & 0.055 \\
Heating oil cost & $€_{2010} / \mathrm{kWh}$ & 0.064 \\
Gas price inflation rate & $(\%)$ & 3 \\
Electricity price inflation rate & $(\%)$ & 3 \\
Heating oil price inflation rate & $(\%)$ & 3 \\
Grant for FPC & $\left(€ / \mathrm{m}^{2}\right)$ & 250 \\
Grant for ETC & $\left(€ / \mathrm{m}^{2}\right)$ & 300 \\
Installed cost of FPC system & $€_{2010}$ & 4400 \\
Installed cost of ETC system & $€_{2010}$ & 5000 \\
System life & Years & 20 \\
Discount rate & $\%$ & 8 \\
\hline
\end{tabular}


Table 3

Average daily solar insolation, energy collected, energy delivered and supply pipe losses for the FPC and ETC systems.

\begin{tabular}{|c|c|c|c|c|c|c|c|c|c|}
\hline \multirow[t]{2}{*}{ Month } & \multirow[t]{2}{*}{$\begin{array}{l}\text { In-plane Solar } \\
\text { insolation }\left(\mathrm{kWh} \mathrm{m}^{-2} \mathrm{~d}^{-1}\right)\end{array}$} & \multicolumn{2}{|c|}{$\begin{array}{l}\text { Total energy } \\
\text { collected }\left(\mathrm{KWh} \mathrm{d}^{-1}\right)\end{array}$} & \multicolumn{2}{|c|}{$\begin{array}{l}\text { Energy delivered } \\
\left(\mathrm{kWh}^{-1}\right)\end{array}$} & \multicolumn{2}{|c|}{$\begin{array}{l}\text { Supply pipe } \\
\text { losses }\left(\mathrm{kWh} \mathrm{d}^{-1}\right)\end{array}$} & \multicolumn{2}{|c|}{$\begin{array}{l}\text { Energy collected per } \\
\text { unit area }\left(\mathrm{kWh} \mathrm{m}^{-2} \mathrm{~d}^{-1}\right)\end{array}$} \\
\hline & & FPC $\left(4 m^{2}\right)$ & $\operatorname{ETC}\left(3 \mathrm{~m}^{2}\right)$ & $\mathrm{FPC}\left(4 \mathrm{~m}^{2}\right)$ & $\operatorname{ETC}\left(3 \mathrm{~m}^{2}\right)$ & $\operatorname{FPC}\left(4 m^{2}\right)$ & $\operatorname{ETC}\left(3 \mathrm{~m}^{2}\right)$ & FPC & ETC \\
\hline Jan-10 & 1.5 & 3.0 & 2.4 & 2.5 & 2.0 & 0.5 & 0.4 & 0.8 & 0.8 \\
\hline Feb-10 & 1.9 & 4.1 & 3.0 & 3.4 & 2.4 & 0.7 & 0.5 & 1.0 & 1.0 \\
\hline Mar-10 & 3.3 & 6.7 & 6.2 & 5.4 & 5.4 & 1.0 & 0.9 & 1.7 & 2.1 \\
\hline Apr-10 & 4.5 & 9.2 & 8.5 & 7.5 & 7.4 & 1.4 & 1.3 & 2.3 & 2.8 \\
\hline May-10 & 4.2 & 7.7 & 9.0 & 6.4 & 7.4 & 1.3 & 1.6 & 1.9 & 3.0 \\
\hline Jun-09 & 4.6 & 8.2 & 9.5 & 7.1 & 7.7 & 1.1 & 1.8 & 2.1 & 3.2 \\
\hline Jul-09 & 3.6 & 5.5 & 6.7 & 4.5 & 5.3 & 1.0 & 1.4 & 1.4 & 2.2 \\
\hline Aug-09 & 3.7 & 5.9 & 7.1 & 5.0 & 5.7 & 1.0 & 1.5 & 1.5 & 2.4 \\
\hline Sep-09 & 3.3 & 5.8 & 6.5 & 4.9 & 5.2 & 0.9 & 1.2 & 1.4 & 2.2 \\
\hline Oct-09 & 2.2 & 3.9 & 4.1 & 3.2 & 3.4 & 0.7 & 0.7 & 1.0 & 1.4 \\
\hline Nov-09 & 1.8 & 3.3 & 3.0 & 2.6 & 2.5 & 0.7 & 0.5 & 0.8 & 1.0 \\
\hline Dec-09 & 1.2 & 2.0 & 1.7 & 1.6 & 1.5 & 0.4 & 0.2 & 0.5 & 0.6 \\
\hline Annual average & 3.0 & 5.4 & 5.6 & 4.5 & 4.6 & 0.9 & 1.0 & 1.4 & 1.9 \\
\hline Annual total & 1,087 & 1,984 & 2,056 & 1,639 & 1,699 & 326 & 366 & 496 & 681 \\
\hline
\end{tabular}

\subsection{Solar fraction}

The solar fraction (SF) is the ratio of solar heat yield to the total energy requirement for water heating and is given as [20]:

$S F=\frac{Q_{s}}{Q_{s}+Q_{\text {aux }}}$

\subsection{Collector efficiency}

The efficiency of the plat plate (FP) and $\mathrm{ET}$ collectors are calculated as [21,22]:

$\eta=\frac{\dot{m} C_{\mathrm{p}}\left(T_{1}-T_{6}\right)}{A_{\mathrm{c}} G_{\mathrm{t}}}$

\subsection{System efficiency}

The efficiency of the FPC and ETC systems ${ }^{\text {is calculated as }}$ [21,22]:

$\eta=\frac{\dot{m} C_{\mathrm{p}}\left(T_{4}-T_{5}\right)}{A_{\mathrm{c}} G_{\mathrm{t}}}$

\section{Economicanalysis}

In order to compare the economic viability of the two $\mathrm{SWH}$ systems, simple payback period (SPP) and net present value (NPV) were used. Calculations were based on potential savings compared to using an electric immersion water heater, a condensing gas boiler and an oil fired boiler. Tables 1 and 2 show the technical and economic parameters used in the economic analysis of the $\mathrm{SWH}$ systems. The quantities of heat delivered by the FPC and ETC systems were obtained from field performance data. The cost of electricity, gas and heating oil used are 2010 market prices in Ireland.

The annual operation and maintenance cost was estimated to be $1 \%$ of the initial capital cost and it was assumed that it increased at a rate of $1 \%$ per year as used by Kalogirou [12]. The system life was assumed to be 20 years which is in line with the duration quoted by most manufacturers/suppliers of SWH collectors.

The SPP is one of the most common ways to evaluate the economic value of a project. It is the minimum amount of time in years required for the positive cash flows to surpass the initial investment, without regard to the time value of money. The main drawbacks of this method are that the timing of cash flows is ignored and cash flows beyond the payback period are not accounted for [23]. However, it has the advantage of being the easiest for the public to understand of all economic measures. The payback period is the ratio of the extra first cost, $\Delta C_{0}$ (or capital cost) to the annual savings, $S$ and is given as [24]:

$\mathrm{SPP}=\frac{\Delta C_{0}}{S}$

The extra first cost is the incremental cost of the $\mathrm{SWH}$ system and does not involve costs that would arise in any other case for the corresponding building component. Annual revenues are the averaged energy cost avoided annually, which consists of the annual energy savings multiplied by the cost per energy unit.

The quantity of conventional energy displaced annually $\left(E_{\mathrm{c}}\right)$ is computed as:

$E_{\mathrm{c}}=Q_{\mathrm{u}} / \eta_{\mathrm{h}}$

where $\eta_{\mathrm{h}}$ is the auxiliary heater efficiency and $Q_{\mathrm{u}}$ is the useful energy collected by the solar collector.

Table 4

Energy extracted from the hot water tanks and auxiliary energy supplied to the FPC and ETC systems

\begin{tabular}{|c|c|c|c|c|c|c|}
\hline \multirow[t]{2}{*}{ Month } & \multicolumn{2}{|c|}{$\begin{array}{l}\text { Energy extracted } \\
\left(\mathrm{kWhd}^{-1}\right)\end{array}$} & \multicolumn{2}{|c|}{$\begin{array}{l}\text { Auxiliary energy } \\
\left(\mathrm{kWhd}^{-1}\right)\end{array}$} & \multicolumn{2}{|c|}{ Solar fraction (\%) } \\
\hline & $\begin{array}{l}\text { FPC } \\
\left(4 \mathrm{~m}^{2}\right)\end{array}$ & $\begin{array}{l}\text { ETC } \\
\left(3 \mathrm{~m}^{2}\right)\end{array}$ & $\begin{array}{l}\text { FPC } \\
\left(4 \mathrm{~m}^{2}\right)\end{array}$ & $\begin{array}{l}\text { ETC } \\
\left(3 \mathrm{~m}^{2}\right)\end{array}$ & $\begin{array}{l}\text { FPC } \\
\left(4 \mathrm{~m}^{2}\right)\end{array}$ & $\begin{array}{l}\text { ETC } \\
\left(3 \mathrm{~m}^{2}\right)\end{array}$ \\
\hline Jan-10 & 13.2 & 12.9 & 11.6 & 11.4 & 20.7 & 17.2 \\
\hline Feb-10 & 13.4 & 13.1 & 11.1 & 11.1 & 26.8 & 21.0 \\
\hline Mar-10 & 12.0 & 11.8 & 8.3 & 8.0 & 44.5 & 43.7 \\
\hline Apr-10 & 14.3 & 14.2 & 6.6 & 6.9 & 58.2 & 56.2 \\
\hline May-10 & 14.9 & 14.3 & 7.4 & 7.2 & 51.0 & 55.4 \\
\hline Jun-09 & 14.8 & 14.2 & 5.4 & 4.9 & 60.4 & 66.1 \\
\hline Jul-09 & 14.9 & 14.3 & 7.3 & 6.7 & 42.9 & 49.8 \\
\hline Aug-09 & 14.7 & 14.3 & 6.9 & 6.4 & 46.4 & 52.7 \\
\hline Sep-09 & 14.3 & 14.0 & 7.6 & 7.3 & 43.2 & 47.1 \\
\hline Oct-09 & 14.0 & 13.7 & 9.2 & 9.0 & 29.7 & 31.2 \\
\hline Nov-09 & 13.9 & 13.4 & 10.5 & 10.3 & 23.8 & 22.2 \\
\hline Dec-09 & 13.4 & 13.1 & 11.8 & 11.6 & 14.6 & 12.7 \\
\hline $\begin{array}{l}\text { Annual } \\
\text { average }\end{array}$ & 14.0 & 13.6 & 8.6 & 8.4 & 38.6 & 40.2 \\
\hline $\begin{array}{l}\text { Annual total } \\
\qquad(\mathrm{kWh})\end{array}$ & $4,591.2$ & $4,455.6$ & $3,149.7$ & $3,053.6$ & & \\
\hline
\end{tabular}


Table 5

FP and ET collector and system efficiencies.

\begin{tabular}{|c|c|c|c|c|}
\hline \multirow[t]{2}{*}{ Month } & \multicolumn{2}{|c|}{ Collector efficiency (\%) } & \multicolumn{2}{|c|}{ System efficiency (\%) } \\
\hline & FPC & ETC & FPC & ETC \\
\hline Jan-10 & 51.5 & 53.5 & 42.2 & 44.1 \\
\hline Feb-10 & 54.5 & 52.6 & 45.6 & 43.2 \\
\hline Mar-10 & 50.0 & 62.3 & 40.3 & 54.4 \\
\hline Apr-10 & 51.6 & 63.2 & 41.7 & 55.0 \\
\hline May-10 & 45.7 & 71.4 & 37.8 & 58.8 \\
\hline Jun-09 & 44.5 & 68.7 & 38.4 & 55.8 \\
\hline Jul-09 & 38.5 & 62.5 & 31.6 & 49.3 \\
\hline Aug-09 & 39.6 & 63.4 & 33.2 & 50.5 \\
\hline Sep-09 & 43.8 & 65.6 & 36.9 & 53.0 \\
\hline Oct-09 & 44.3 & 62.2 & 36.2 & 51.3 \\
\hline Nov-09 & 45.5 & 54.6 & 36.4 & 45.5 \\
\hline Dec-09 & 43.7 & 48.3 & 34.9 & 42.8 \\
\hline Annual average & 46.1 & 60.7 & 37.9 & 50.3 \\
\hline
\end{tabular}

The total life cycle cost of the SWH systems $(C)$ is the sum of the capital cost $\left(C_{0}\right)$ and the operation and maintenance cost $\left(C_{0 \& \mathrm{M}}\right)$ given as:

$C=C_{0}+C_{\mathrm{O} \& \mathrm{M}}$

$C_{\mathrm{O \& M}}=\sum_{n=1}^{n=N} \frac{c_{\mathrm{O \& M}}(1+e)^{n}}{(1+d)^{n}}$

where, $c_{0} \& \mathrm{M}$ is the annual operation and maintenance cost, $e$ is the fuel annual escalation rate, $N$ is the service life and $\mathrm{d}$ the discount rate.

The total revenue $\left(R_{\mathrm{t}}\right)$ accrued over the service life of the SWH system is given as:

$R_{\mathrm{t}}=\frac{Q_{\mathrm{u}}}{\eta_{\mathrm{h}}} \sum_{n=1}^{n=N} \frac{(1+e)^{n}}{(1+d)^{n}}$

The $_{\perp} \mathrm{NPV}$ for the $\mathrm{SWH}_{\mathbf{L}}$ systems is given as:

$\mathrm{NPV}=R_{\mathrm{t}}-\mathrm{C}$

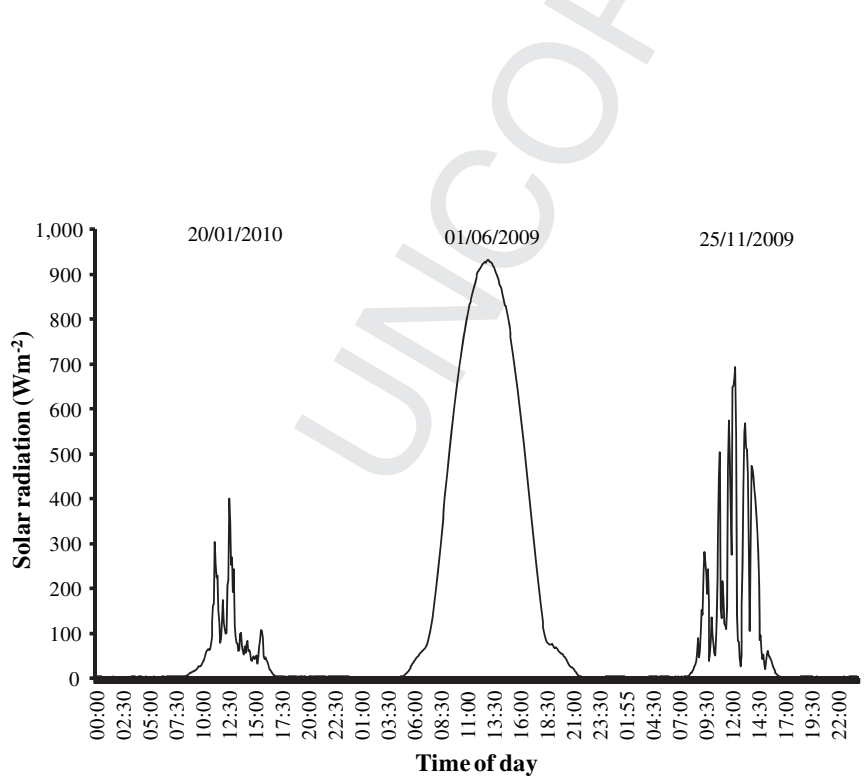

Fig. 3. In-plane global solar radiation for three characteristic days.

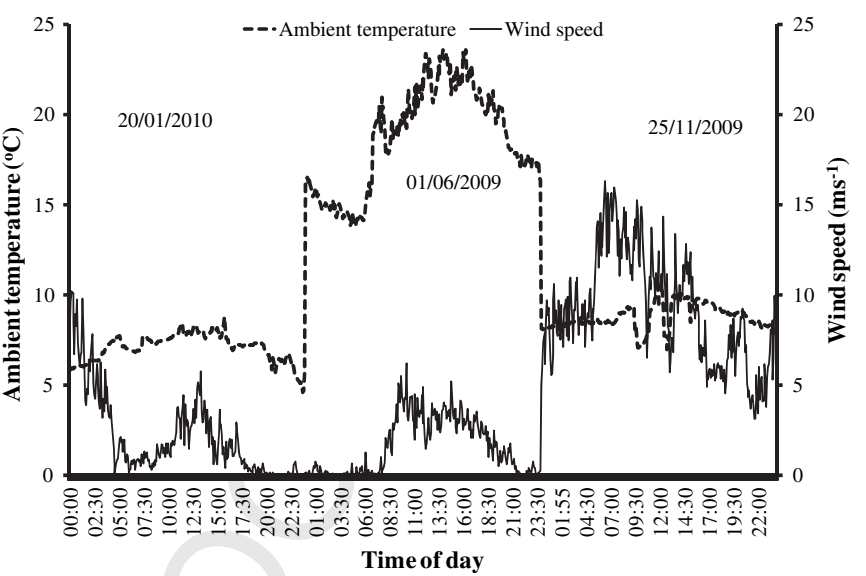

Fig. 4. Ambient air temperature and wind speed for three characteristic days.

\section{5. $\Lambda^{\text {Results and discussions }}$}

\subsection{Energy collected}

Table 3 shows average daily solar insolation, energy collected, energy delivered and supply pipe losses from the FPC and ETC systems. The average daily energy collected by the FPC ranged between $2.0 \mathrm{kWh} \mathrm{d}^{-1}$ and $9.2 \mathrm{kWh} \mathrm{d}^{-1}$ in December and April respectively, while it ranged between $1.7 \mathrm{kWh} \mathrm{d} \mathrm{d}^{-1}$ and $9.5 \mathrm{kWh} \mathrm{d}^{-1}$ in December and June respectively. The annual total energy collected by the $4 \mathrm{~m}^{2}$ FPC and $3 \mathrm{~m}^{2}$ ETC was $1984 \mathrm{kWh} \mathrm{y}^{-1}$ and 2056 $\mathrm{kWh} \mathrm{y}^{-1}$ respectively. The $3 \mathrm{~m}^{2}$ ETC system therefore generated 3.5\% more energy than the $4 \mathrm{~m}^{2} \mathrm{FPC}$ system. The results also show that over the year a unit area of FPC and ETC generated $496 \mathrm{kWh} \mathrm{m}^{-2} \mathrm{y}^{-1}$ and $681_{\Lambda} \mathrm{kWh} \mathrm{m}^{-2} \mathrm{y}^{-1}$ of heat energy respectively.

\subsection{Energy delivered and supply pipe losses}

It is seen in Table 3 that the FPC system delivered a daily average of $1.6 \mathrm{kWh} \mathrm{d}^{-1}$ and $7.5 \mathrm{kWh} \mathrm{d}^{-1}$ of heat energy in December and April respectively while the ETC system delivered a daily average of 1.5 $\mathrm{kWh} \mathrm{d}^{-1}$ and $7.7_{\Lambda} \mathrm{kWh} \mathrm{d}^{-1}$ of heat energy in December and June respectively.

Heat losses occur along the supply side of the solar circuit especially at high collector outlet temperatures. The FPC and ETC systems had annual supply pipe heat losses of 326. $\mathrm{kWh} \mathrm{y}^{-1}$ and 366 $\mathrm{kWh} \mathrm{y}^{-1}$ respectively corresponding to $16.4 \%$ and $17.8 \%$ of energy collected.

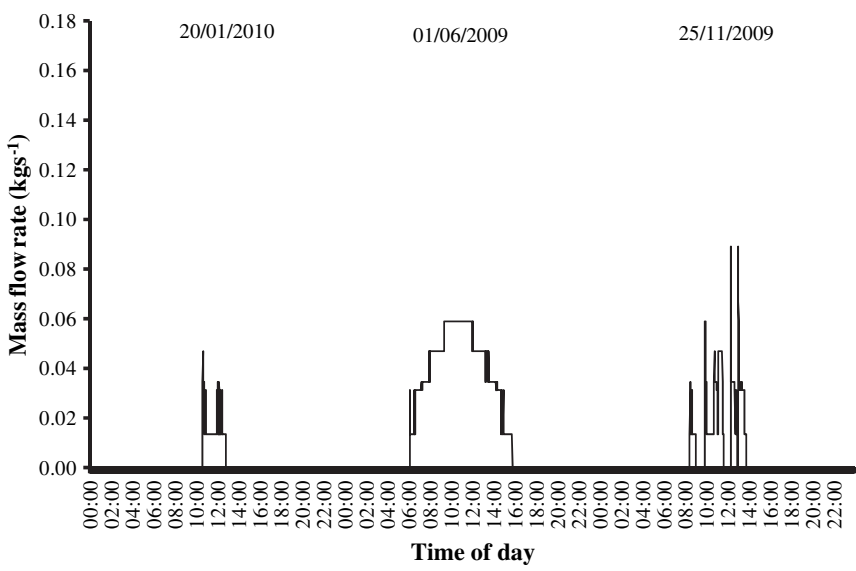

Fig. 5. Solar fluid mass flow rate for the FPC system. 


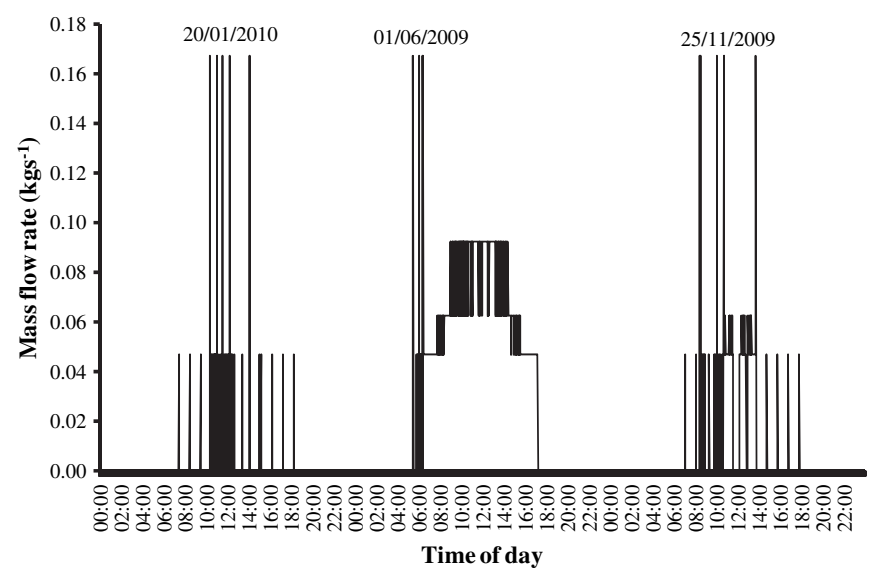

Fig. 6. Solar fluid mass flow rate for the ETC system.

These losses are quite significant representing $65.7 \%$ and $53.7 \%$ of the energy generated by a unit area of FPC and ETC respectively annually. The supply pipe length should therefore be kept as short as possible and all joints insulated to reduce heat losses.

\subsection{Energy extracted and auxiliary energy}

Table 4 shows monthly average daily, annual average and annual total energy extracted from the hot water tanks and auxiliary energy supplied to the FPC and ETC systems. During the monitoring period a total of $4591.2 \mathrm{kWh}$ and $4455.6 \mathrm{kWh}$ of heat energy were extracted from the hot water tanks of the FPC and ETC systems respectively. The results also show that the monthly average quantity of auxiliary energy added varied between $5.4 \mathrm{kWh} \mathrm{d}^{-1}$ and 4.9. $\mathrm{kWh} \mathrm{d}^{-1}$ in June and $11.8 \mathrm{kWh}$ and $11.6 \mathrm{kWh}$ in December for the FPC and ETC systems respectively.

\subsection{Solar fraction}

Table 4 shows the monthly and annual $S$ F for the FPC and ETC systems. The SF of the FPC system range between $14.6 \%$ and $60.4 \%$ in December and June respectively while the SF for the ETC ranged between $12.7 \%$ and $66.1 \%$ in December and June respectively. It is seen that the FPC system had higher SF between January and April as well as November and December while the ETC system had higher SF between May and October. The FPC and ETC systems had annual average SFs of $38.6 \%$ and $40.2 \%$ respectively. It is seen that

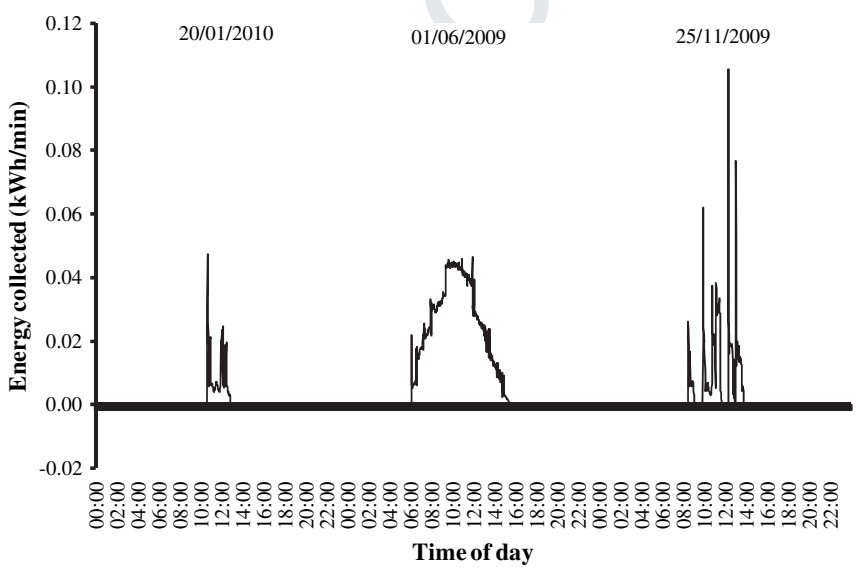

Fig. 7. Energy collected by the FPC system.

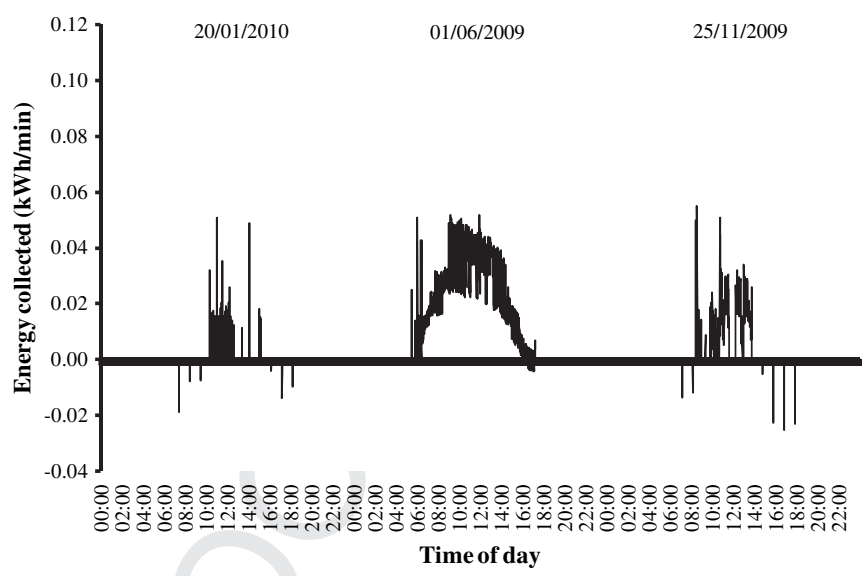

Fig. 8. Energy collected by the ETC system.

the quantity of energy required for auxiliary heating decreases with increase in SF.

\subsection{Collector and system efficiency}

Table 5 shows results of collector and system efficiencies for the FPC and ETC systems. The respective minimum and maximum efficiencies of the FPCs was $38.5 \%$ in July and $54.5 \%$ in February while those of the ETCs were $48.3 \%$ in December and $71.4 \%$ in May. Similarly, the range of efficiencies of the overall FPC system varied from $31.6 \%$ in July to $45.6 \%$ in February and from $42.8 \%$ in December to $58.8 \%$ in May for the ETC system.

\subsection{Daily performance}

\subsubsection{Solar radiation}

Fig. 3 shows plots of in-plane global solar radiation for three 'typical' days characterised by heavily overcast sky (20/01/2010), clear sky (1/06/2009) and intermittent cloud covered sky (25/11/ 09) measured at 5 min intervals. The maximum solar radiation was $398.8 \mathrm{~W} \mathrm{~m}^{-2}, 932.1 \mathrm{~W} \mathrm{~m}^{-2}$ and $692.5 \mathrm{~W} \mathrm{~m}^{-2}$ on the heavily overcast, clear and intermittent cloud covered sky days respectively.

\subsubsection{Ambient temperature and wind speed}

Fig. 4 shows plots of ambient air temperature and wind speed for the three days measured at $5 \mathrm{~min}$ intervals. The maximum ambient air temperatures were $8.8^{\circ} \mathrm{C}, 2 \frac{\widehat{3}}{3} 6^{\circ} \mathrm{C}$ and $10.3^{\circ} \mathrm{C}$ while the maximum wind speeds were $10.2_{\Lambda} \mathrm{m} \mathrm{s}^{-1}, 6.2_{\Lambda} \mathrm{m} \mathrm{s}^{-1}$ and $16.3_{\Lambda} \mathrm{m} \mathrm{s}^{-1}$

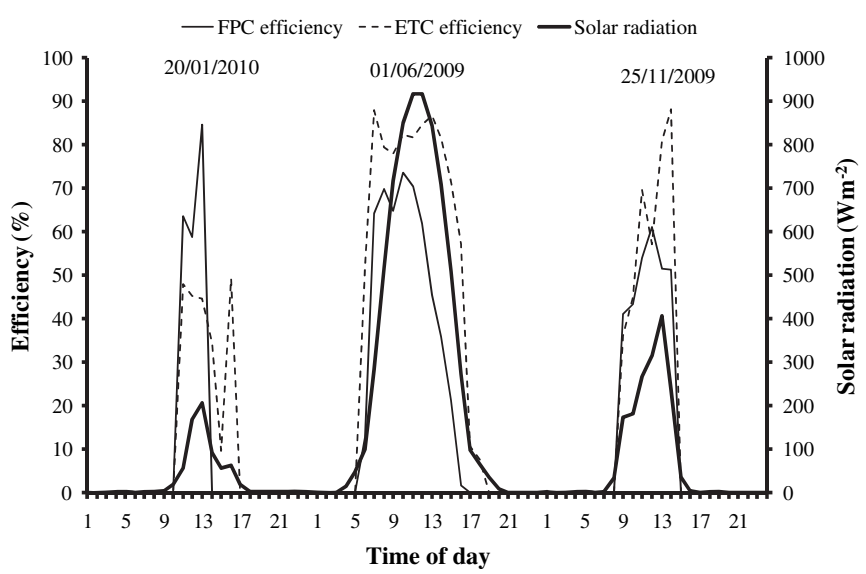

Fig. 9. Hourly global in-plane solar radiation, FPC and ETC efficiencies. 
Table 6

Seasonal values of solar insolation, energy collected, energy delivered, supply pipe losses and energy collected per unit area for the FPC and ETC systems.

\begin{tabular}{|c|c|c|c|c|c|c|c|c|c|}
\hline \multirow[t]{2}{*}{ Season } & \multirow[t]{2}{*}{$\begin{array}{l}\text { Solar insolation } \\
\left(\mathrm{kWh} \mathrm{m}^{-2} \mathrm{~d}^{-1}\right)\end{array}$} & \multicolumn{2}{|c|}{$\begin{array}{l}\text { Energy collected } \\
\left(\mathrm{KWh} \mathrm{d}^{-1}\right)\end{array}$} & \multicolumn{2}{|c|}{$\begin{array}{l}\text { Energy delivered } \\
\left(\mathrm{kWh}^{-1}\right)\end{array}$} & \multicolumn{2}{|c|}{$\begin{array}{l}\text { Supply pipe losses } \\
\left(\mathrm{kWh}^{-1}\right)\end{array}$} & \multicolumn{2}{|c|}{$\begin{array}{l}\text { Energy collected } \\
\text { per unit area }\left(\mathrm{kWh} \mathrm{m}^{-2} \mathrm{~d}^{-1}\right)\end{array}$} \\
\hline & & $\mathrm{FPC}\left(4 \mathrm{~m}^{2}\right)$ & $\operatorname{ETC}\left(3 \mathrm{~m}^{2}\right)$ & $\mathrm{FPC}\left(4 \mathrm{~m}^{2}\right)$ & $\operatorname{ETC}\left(3 \mathrm{~m}^{2}\right)$ & $\operatorname{FPC}\left(4 m^{2}\right)$ & $\operatorname{ETC}\left(3 \mathrm{~m}^{2}\right)$ & FPC & ETC \\
\hline Winter & 1.5 & 3.0 & 2.3 & 2.5 & 2.0 & 0.5 & 0.4 & 0.8 & 0.8 \\
\hline Spring & 4.0 & 7.9 & 7.9 & 6.4 & 6.7 & 1.2 & 1.3 & 2.0 & 2.6 \\
\hline Summer & 4.0 & 6.5 & 7.8 & 5.5 & 6.2 & 1.0 & 1.5 & 1.6 & 2.6 \\
\hline Autumn & 2.4 & 4.3 & 4.5 & 3.6 & 3.7 & 0.8 & 0.8 & 1.1 & 1.5 \\
\hline
\end{tabular}

on the heavily overcast, clear and intermittent cloud covered sky days respectively.

\subsubsection{Solar fluid mass flow rate}

The two systems both had variable speed pumps controlled by the Resol DeltaSol M controller. Fig. 5 shows plots of the solar fluid mass flow rate for the FPC system. During the heavily overcast day the mass flow rate was largely below $0.02 \mathrm{~kg} \mathrm{~s}^{-1}$ and only occasionally reached $0.04 \mathrm{~kg} \mathrm{~s}^{-1}$. During the clear sky day the mass flow rate showed a more regular pattern at sunrise and sunset peaking at $0.068 \mathrm{~kg} \mathrm{~s}^{-1}$. During the day with intermittent cloud cover, the mass flow rate peaked at $0.088 \mathrm{~kg} \mathrm{~s}^{-1}$ and was occasionally zero.

Fig. 6 shows plots of the solar fluid mass flow rate for the ETC system. During the heavily overcast day the pump cycled on and off regularly to peaks of $0.045 \mathrm{~kg} \mathrm{~s}^{-1}$. During the clear sky day the pump operated largely continuously between $0.045 \mathrm{~kg} \mathrm{~s}^{-1}$ and $0.098 \mathrm{~kg} \mathrm{~s}^{-1}$, peaking intermittently at $0.168 \mathrm{~kg} \mathrm{~s}^{-1}$ during early morning. During the day with intermittent cloud cover the mass flow rate occasional peaked at $0.17_{\Lambda} \mathrm{kg} \mathrm{s}^{-1}$ but was typically $0.056 \mathrm{Kg} \mathrm{s}^{-1}$.

\subsubsection{Energy collected}

Fig. 7 shows plots of the energy collected by the FPC system at $1 \mathrm{~min}$ intervals. It can be seen that the total energy collected during the days with heavily overcast and intermittent cloud cover was very low with intermittent spikes as a result of the pump turning on and off as the intensity of solar radiation varied. The energy collected during the clear sky day peaked at around solar noon.

Fig. 8 shows plots of the energy collected by the ETC system. Unlike the FPC system, the ETC system tends to operated during low levels of solar insolation at sunrise and sunset. This has an impact on the quantity of energy collected since short intermittent flows of the solar fluid tends to carry heat away from the hot water tank and dump it into the collector leading to energy losses as seen on the $20 / 01 / 2010$ and $25 / 11 / 2009$. This results in a reduction in the energy collected and, in some periods during the cold winter months to net negative energy balances. This shows that there is scope for improvement in the operation of ETC systems equipped with heat pipe collectors.

\subsubsection{Collector efficiency}

Fig. 9 shows plots of hourly global in-plane solar radiation, FPC and ETC efficiencies on the 20/01/2010, 01/06/2009 and 25/11/ 2009. It is seen that during the heavily overcast day in winter (20/
$01 / 2010$ ) with a maximum hourly solar radiation of $207, \mathrm{~W} \mathrm{~m}^{-2}$, the FPC and ETC had maximum hourly efficiencies of $84.7 \%$ and $48.0 \%$ respectively. During the clear sky day in summer (01/06/2009) with a maximum hourly solar radiation of $918 \mathrm{~W} \mathrm{~m}^{-2}$, the ETC was more efficient than the FPC with maximum hourly efficiency of $88.1 \%$ compared to $73.7 \%$ for the FPC. During the intermittently cloud covered day in Autumn (25/11/2009) with a maximum hourly solar radiation of $407, \mathrm{~W} \mathrm{~m}^{-2}$, the ETC was again more efficient than the FPC with maximum hourly efficiency of $88.2 \%$ compared to $61.1 \%$ for the FPC. The results show that the FPC was more efficient than the ETC during days with low levels of solar radiation while the ETC was more efficient during days with high levels of solar radiation and intermittent cloud cover.

\subsection{Seasonal performance}

Table 6 shows seasonal daily average values of solar insolation, energy collected, energy delivered and supply pipe losses. It is seen that the $4 \mathrm{~m}^{2}$ FPC system collected and delivered more heat energy than the $3 \mathrm{~m}^{2}$ ETC system in winter. Both systems collected $7.9 \mathrm{kWh} \mathrm{d}^{-1}$ of heat energy in Spring while the ETC system collected and delivered more heat energy than the FPC system in Summer and Autumn. The supply pipe losses for the FPC and ETC systems were highest in Spring and Summer respectively.

Table 7 shows seasonal average daily collector and system efficiencies, energy extracted and auxiliary energy for the FPC and ETC systems. The collector and system efficiencies for the FPC ranged from $40.9 \%$ in summer to $49.9 \%$ in winter while those for the ETC ranged from $51.5 \%$ in winter to $65.6 \%$ in spring. These results show that the FPC system was most efficient in winter while the ETC was most efficient in Spring. 6.5 $\mathrm{kWh} \mathrm{d}^{-1}$ and $6.0 \mathrm{kWh} \mathrm{d}^{-1}$ of auxiliary energy was added to the FPC and ETC system hot water tanks respectively using the electric immersion heaters in summer, while 11.5 $\mathrm{kWh} \mathrm{d}^{-1}$ and $11.3_{\mathrm{L}} \mathrm{kWh} \mathrm{d}^{-1}$ was added in winter.

\subsection{Simple payback period}

Fig. 10 shows plots of SPPs for SWH systems fitted with different types of auxiliary heaters. It is seen that systems fitted with electric immersion heaters had the lowest SPPs while the systems using condensing boiler auxiliary heaters had the highest payback periods. The SPPs vary between 13.0 years and 48.5 years for FPC systems with grant aid fitted with electric immersion heaters and

Table 7

Seasonal average daily collector and system efficiencies, energy extracted and auxiliary energy for the FPC and ETC systems.

\begin{tabular}{|c|c|c|c|c|c|c|c|c|}
\hline \multirow[t]{2}{*}{ Season } & \multicolumn{2}{|c|}{ Collector efficiency (\%) } & \multicolumn{2}{|c|}{ System efficiency (\%) } & \multicolumn{2}{|c|}{ Energy extracted $\left(\mathrm{kWhd}^{-1}\right)$} & \multicolumn{2}{|c|}{ Auxiliary energy $\left(\mathrm{kWhd}^{-1}\right)$} \\
\hline & $\mathrm{FPC}\left(4 \mathrm{~m}^{2}\right)$ & $\operatorname{ETC}\left(3 \mathrm{~m}^{2}\right)$ & $\operatorname{FPC}\left(4 \mathrm{~m}^{2}\right)$ & $\operatorname{ETC}\left(3 \mathrm{~m}^{2}\right)$ & $\operatorname{FPC}\left(4 \mathrm{~m}^{2}\right)$ & $\operatorname{ETC}\left(3 \mathrm{~m}^{2}\right)$ & FPC & ETC \\
\hline Winter & 49.9 & 51.5 & 40.9 & 43.4 & 13.3 & 13.0 & 11.5 & 11.3 \\
\hline Spring & 49.1 & 65.6 & 39.9 & 56.1 & 13.7 & 13.4 & 7.4 & 7.4 \\
\hline Summer & 40.9 & 64.9 & 34.4 & 51.9 & 14.8 & 14.3 & 6.5 & 6.0 \\
\hline Autumn & 44.6 & 60.8 & 36.5 & 49.9 & 14.1 & 13.7 & 9.1 & 8.9 \\
\hline
\end{tabular}




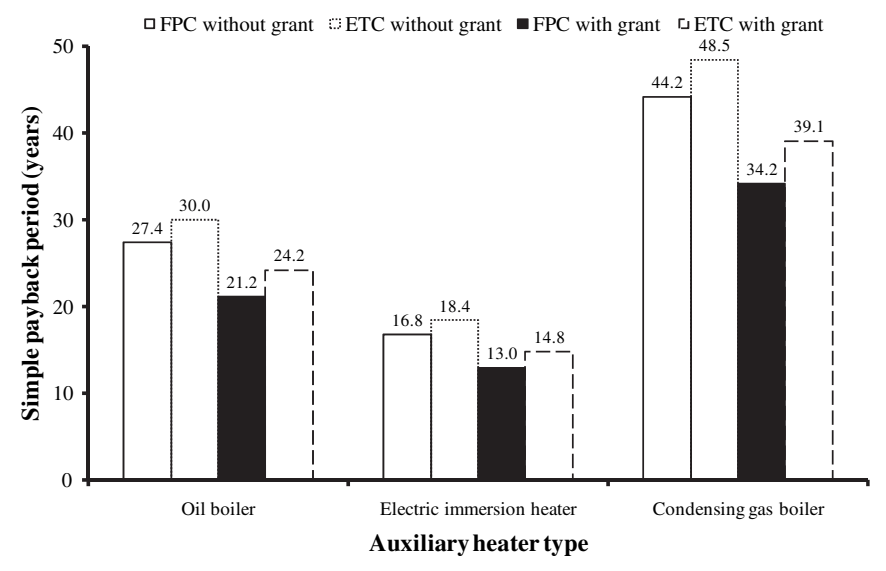

Fig. 10. Simple payback period for different types of auxiliary heaters.

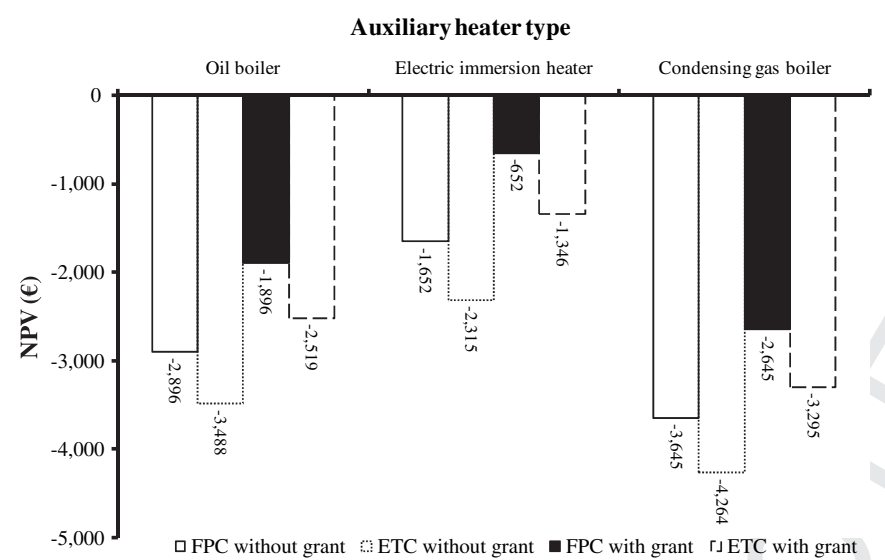

Fig. 11. Net present value for different auxiliary heater types.

ETC systems without grant aid fitted with condensing gas boilers respectively.

\subsection{Net present value}

Fig. 11 shows plots of the ${ }_{1}$ NPV for SWH systems fitted with different types of auxiliary heaters. It can be seen that over the anticipated service life of 20 years, none of the $S W H$ systems was economically viable. The FPC SWH system with grant aid fitted with an immersion heater had the best NPV of $-€ 652$ while the ETC system without grant aid fitted with a condensing gas boiler had the worst NPV of $-€ 4264$. The results showed that under prevailing system costs (2010), existing grant aid structure and the assumed discount rate, $\mathrm{SWH}$ systems are not yet economically viable in Ireland.

\section{6. $\Lambda_{\text {Conclusions }}$}

The year round energy performance analysis of two commonly installed forced circulation SWH systems in temperate climates has been carried out using trial installations in Dublin, Ireland. The SWH systems were designed and operated to mimic real life operation of taking into consideration interaction between the collectors, storage tank and users. An immersion heater was used to supply auxiliary energy when the solar coil was unable to raise the tank water temperature to the required temperature.

Results obtained show that for an annual total in-plane solar insolation of $1087 \mathrm{kWh} \mathrm{m}^{-2}$, a total of $1984 \mathrm{kWh}$ and $2056 \mathrm{kWh}$ of heat energy were collected by the $4 \mathrm{~m}^{2}$ FPC and $3 \mathrm{~m}^{2}$ ETC systems respectively. Over the year, a unit area of the FPC and ETC each generated $496 \mathrm{kWh} \mathrm{m}^{-2}$ and $681 \mathrm{kWh} \mathrm{m}^{-2}$ of heat respectively. For $3149.7 \mathrm{kWh}$ and $3053.6 \mathrm{kWh}$ of auxiliary energy supplied to the FPC and ETC systems their annual SFs were $38.6 \%$ and $40.2 \%$ respectively. The annual average collector efficiencies were $46.1 \%$ and $60.7 \%$ while the system efficiencies were $37.9 \%$ and $50.3 \%$ respectively for the FPC and ETC respectively. Economic analysis showed that both SWH systems are not economically viable with NPVs ranging between -€4264 and -€652 while SPPs varied between 13 years and 48.5 years.

The results of the energy performance analysis show that the $4 \mathrm{~m}^{2}$ FPC system compares quite favourably with the $3 \mathrm{~m}^{2}$ ETC system when connected to a 3001 hot water tank. These results are useful as they would provide valuable information to households, policy makers and installers.

\section{Nomenclature}

$A_{\mathrm{c}}$ : collector area $\left(\mathrm{m}^{2}\right)$

$C_{\mathrm{p}}$ : specific heat capacity of solar fluid $\left(\mathrm{J} \mathrm{kg}^{-1} \mathrm{~K}^{-1}\right)$

$C_{0}$ : capital cost $(€)$

$C_{\mathrm{O} \& \mathrm{M}}$ : operation and maintenance cost $(€)$

$\Delta C_{0}$ : extra first cost $(€)$

$d$ : discount rate (\%)

$e$ : fuel annual escalation rate (\%)

$E_{c}$ : conventional energy displaced (kWh)

ET: evacuated tube

ETC: evacuated tube collector

FP: flat plate

FPC: flat place collector

$G_{\mathrm{t}}$ : total in-plane solar radiation $\left(\mathrm{W} \mathrm{m}^{-2}\right)$

$\dot{m}$ : solar fluid mass flow rate $\left(\mathrm{kg} \mathrm{s}^{-1}\right)$

$N$ : service life (years)

NPV: net present value $(€)$

$Q_{\text {aux }}$ : auxiliary heating requirement $(\mathrm{kWh})$

$Q_{c}$ : useful heat collected (W)

$Q_{d}$ : useful heat delivered (W)

$Q_{1}$ : supply pipe heat loss $(\mathrm{W})$

$Q_{s}$ : solar yield ( $\mathrm{kWh}$ )

$Q_{\mathrm{u}}$ : useful energy collected by the solar collector (kWh)

$R_{\mathrm{t}}$ : total revenue $(€$ )

$S$ : annual savings $(€)$

SF: solar fraction (\%)

SPP: simple payback period (years)

SWH: solar water heater

$T_{\mathrm{a}}$ : ambient temperature $\left({ }^{\circ} \mathrm{C}\right)$

Greek symbols

$\eta_{c}$ : collector efficiency (\%)

$\eta_{\mathrm{h}}$ : auxiliary heater efficiency (\%)

\section{References}

[1] Windeleff J, Beuse E, Dubuisson X. Campaign for take off for active solar thermal energy in Ireland - phase one: action plan and strategy. Danish Energy Authority; 2004.

[2] Azad E. Theoretical and experimental investigation of heat pipe solar collector. Experimental Thermal and Fluid Science 2008;32(8):1666-72.

[3] Hussein HMS. Theoretical and experimental investigation of wickless heat pipes flat plate solar collector with cross flow heat exchanger. Energy Conversion and Management 2007;48(4):1266-72.

[4] Hammad M. Experimental study of the performance of a solar collector cooled by heat pipes. Energy Conversion and Management 1995;36(3):197-203.

[5] Mathioulakis E, Belessiotis V. A new heat-pipe type solar domestic hot water system. Solar Energy 2002;72(1):13-20.

[6] Tiwari RC, Kumar A, Gupta SK, Sootha GD. Thermal performance of flat-plate solar collectors manufactured in India. Energy Convers Manage 1991;31(4):309-13. 
[7] Dang A, Sharma JK. Performance of flat plate solar collectors in off-south orientation in India. Energy Convers Manage 1983;23(3):125-30.

[8] Amer EH, Nayak JK, Sharma GK. Transient method for testing flat-plate solar collectors. Energy Convers Manage 1998;39(7):549-58.

[9] Alvarez A, Cabeza O, Muñiz MC, Varela LM. Experimental and numerical investigation of a flat-plate solar collector. Energy 2010;35(9):3707-16.

[10] Zambolin E, Del Col D. Experimental analysis of thermal performance of flat plate and evacuated tube solar collectors in stationary standard and daily conditions. Solar Energy 2010;84(8):1382-96.

[11] Allen SR, Hammond GP, Harajli HA, McManus MC, Winnett AB. Integrated appraisal of a solar hot water system. Energy; 35(3):1351-1362.

[12] Kalogirou S. Thermal performance, economic and environmental life cycle analysis of thermosiphon solar water heaters. Solar Energy 2009;83(1):39-48.

[13] Roonprasang N, Namprakai P, Pratinthong N. Experimental studies of a new solar water heater system using a solar water pump. Energy 2008;33(4):639-46.

[14] Chien CC, Kung CK, Chang CC, Lee WS, Jwo CS, Chen SL. Theoretical and experimental investigations of a two-phase thermosyphon solar water heater. Energy 2011;36(1):415-23.

[15] Huang J, Pu S, Gao W, Que Y. Experimental investigation on thermal performance of thermosyphon flat-plate solar water heater with a mantle heat exchanger. Energy 2010;35(9):3563-8.
[16] Al-Nimr MA, Alkam MK. A modified tubeless solar collector partially filled with porous substrate. Renewable Energy 1998:13(2):165-73.

[17] Al-Nimr MA, Kiwan S, Al-Alwah A. Size optimization of conventional solar collectors. Energy 1998;23(5):373-8.

[18] European Commission. Mandate to CEN and CENELEC for the elaboration and adoption of measurement standards for household appliances: water heaters, hot water storage appliances and water heating systems; 2002. Brussels.

[19] Kalogirou SA. Solar energy engineering: processes and systems. London: Elsevier; 2009.

[20] The German Solar Energy Society. Planning and installing solar thermal systems: a guide for installers, architects and engineers. UK: James and James; 2007.

[21] Sukhatme SP. Solar energy: principles of thermal collection and storage. 2nd ed. New Delhi: Tata McGraw-Hill; 1998.

[22] Duffie JA, Beckman WA. Solar engineering of thermal processes. New York: Wiley; 1991.

[23] Kaplan S. Energy economics: quantitative methods for energy and environmental decisions. New York: McGraw-Hill; 1983.

[24] Masters GM. Renewable and efficient electric power systems. New Jersey: John Wiley and Sons; 2004. 